\title{
Modernity and human rights: beyond a simple association
}

\author{
Modernidade e direitos humanos: para além da simples associação
}

\section{Leno Francisco Danner*}

Universidade Federal de Rondônia, (UNIR), Porto Velho, RO, Brasil

\section{Abstract}

Beginning with the Jürgen Habermas' reconstruction of a normative model of European cultural modernity as basis to a contemporary notion of epistemological-moral universalism as condition to critic, to integration and to intervention, which leads to the affirmation that democracy and human rights represent the modernity's fundamental legacy, I will discuss that such theoretical reconstruction only can be possible from a historical-sociological blindness which is based on the separation between a normative notion of European cultural modernity and the Realpolitik of colonialism - just from this theoretical-political standpoint it is possible to sustain a universalistic normative paradigm which is capable to ground the criticism, the integration and the intervention of all social-cultural contexts, which means that modern culture and normativism can serve as medium and guide of all particular cultures, at least in a strong way. Against that optimistic role of the Habermasian normative model of European cultural modernity, I will argue that democracy and human rights as modernity's legacy have basically two tasks in the contemporary Realpolitik: first, to restrain the modernity's totalizing tendency

* LFD: Doutor em Filosofia, e-mail: leno_danner@yahoo.com.br. 
to rationalization and to globalization, i.e. its movement of assimilation of all cultures and societies in a model of epistemological, cultural and economic universalism; and to ground an international institutional politics based on the social-economic reparation for the colonialism, which implies in a universalistic extension of the social rights to all people in the world (for example, the Philippe van Parijs' idea of basic income).

Keywords: Human rights. Modernity. Colonialism. Self-Limiting. Duty for reparation.

\section{Resumo}

Partindo da reconstrução, por Jürgen Habermas, de um modelo normativo de modernidade cultural europeia como base para uma noção contemporânea de universalismo epistemológico-moral enquanto condição para a crítica, para a integração e para a intervenção, o que leva à afirmação de que a democracia e os direitos humanos são o legado fundamental da modernidade, eu defenderei que tal reconstrução somente pode ser possível a partir de uma cegueira histórico-sociológica que está baseada em uma separação entre uma noção normativa de modernidade cultural europeia e a Realpolitik do colonialismo - apenas desde esse pilar teórico-político é possível sustentar um paradigma normativo universalista que tem condições de crítica, de integração e de intervenção em relação a todos os contextos socioculturais particulares, pelo menos em um sentido poderoso. Contra esse status otimista do modelo normativo de modernidade cultural europeia em Habermas, argumentarei que a democracia e os direitos humanos, enquanto o legado fundamental da modernidade, têm basicamente duas tarefas na Realpolitik contemporânea: conter a tendência totalizante da modernidade à racionalização e à globalização, isto é, seu movimento de assimilação de todas as culturas e sociedades em um modelo de universalismo epistemológico, cultural e econômico; e fundamentar uma política institucional internacional baseada na reparação socioeconômica pelo colonialismo, o que implica em uma extensão universalista dos direitos sociais a todas as pessoas do mundo (por exemplo, a ideia de uma renda básica de cidadania, de Philippe Van Parijs).

Palavras-Chave: Direitos humanos. Modernidade. Colonialismo. Autolimitação. Dever de reparação. 


\section{Introduction}

The picture of Aylan Kurdi's body, dead by drowning in a Turkey's beach, shocks us by an obvious fact: even today, in a very developed modern world, there are many people leaving their countries in search for a better place to live, dying sometimes doing that. But a more critical view on this problem, and particularly on the Aylan Kurdi's death, leads us to perceive that Western imperial colonialism is very living not only as cultural-economic globalization, but also as strategic political destabilization and ideological delegitimation of all countries and all governments which are not aligned to Western cultural-political-economic systemic constitution (American, British, German and French international politics basically). That is the main contemporary political question when we think on international politics, global inequalities, social justice and cultural-economic globalization. And that is the fundamental question also when we think on the normative-political consequences of a human rights policy: generally we associate human rights and modernity, as we associate human rights and the critic to traditional cultures. Here, it seems to be a direct or a natural linking between modern normativism, democracy and human rights, the same way that universalism, democracy and human rights appear to be a direct or a natural consequence of the modernization. One consequence of such linking is the fact that human rights (and even democracy) are used as normative criteria to the critic of the non-modern contexts, putting aside the very problematic modern self-assumed linking between modernity and universalism (democracy and human rights). Other consequence is the fact that modernity can self-assume a universalistic role and range, becoming the very normative criteria and guide to a globalized world which (according to modernity's self-understanding) needs universalism urgently and desperately.

In this paper, I will argue, based on the analysis of the Habermas's reconstruction of a normative model of European cultural modernity as enabling a universalistic epistemological-moral paradigm to critic, to integration and to intervention, that such pure and direct self-association between modernity and universalism (as the association 
between modernity, democracy and human rights) only can be possible by a historical-sociological blindness characterized for the separation between a normative modern self-comprehension founded on universalism, and the Reapolitik of the old and of the new colonialism (which is founded on a notion of normative universalism too). Such separation is very dangerous theoretically and politically speaking, because it gives always an excuse to the totalizing prosecution of the cultural-political-economic modernization which assimilates all contexts based on the epistemological, cultural and economic rationalization. Such separation implies in the correlative naive belief that European rationalism can restrain modernization's economic-technical pathologies, at the same time that modern universalism can serve as epistemological-political paradigm to a global cosmopolitanism. However, the epistemological-moral universalism and the economic-political globalization have the same dynamics: to put themselves as a general context from which all cultures and ways of life - and particularly traditional cultures and ways of life - have sense and orientation, delegitimizing the traditionalism as an alternative to the modernization's problems, and putting democracy and human rights basically as counterpoints of the traditionalism, and not of modernization itself. From this point, I will argue that the only task for democracy and human rights is both the restraining of the Western modernization's totalizing global project, and the social-economic reparation of all people for European and American colonialism - here, the Van Parijs' idea of a universal basic income could be an effective international human rights policy assumed by Western governments and economic institutions, and by Western peoples as well.

\section{The modernity's legacy}

The modernity's normative self-comprehension is characterized by its claim of a universalistic sense and range, which enable it to sustain itself both as universal epistemological-moral paradigm to the critic and to the intervention, and as ethical-political cosmopolitan project 
of social-cultural integration. The reason's tribunal as guide to culture and science is the modern normative pattern from which the own modernity and also non-modern contexts (from the modern perspective, of course) could be unified and integrated based on an objective principle and practice: the rationalism itself. So, modernity's legacy, founded on a notion of rationalism marked by an idea of human nature as cognitive-moral essence, emphasizes the epistemological-moral universalism as the condition to legitimation of the particular contexts (allowing the connection and the intersection between them), and as normative point to integration of such particular contexts: this is the sense of the modern universalism as guide of culture (all cultures) and of science (see Habermas, 1989, p. 17-35). The contemporary critics to modern epistemological-moral universalism did not delegitimize completely such modern universalist sense and claim, which maintain in current philosophical theories (such as Karl-Otto Apel, Jürgen Habermas and Rainer Forst) its very basic starting point: the universalism is the condition to particularism; without the universalist epistemological-moral paradigm, the critic, the intervention and the integration of the particular contexts are not possible, because of the fact that the very own contexts (their proper self-referential and self-subsisting dynamics) cannot ground a critic against their own constitution and evolution - only a universalist epistemological-moral paradigm can do this.

This is the central scope of the Habermas' theory of modernity: to reconstruct an idealized normative model of the modern European culture which can sustain a post-metaphysical epistemological-moral paradigm to the critic, to the intervention and to the integration (see Habermas, 2012a, p. 09-14; 2002a, p. 07; 1997, p. 143). Against conservative traditionalism which bases itself on a naturalized notion of community and normativity (see Dubiel, 1993, p. 17-85; Habermas, 1997, p. 27, p.115; 2002b, p. 06-07), and against post-modern theories which deny the notion of universalism as condition to legitimation of the particular contexts (see Lyotard, 1999, p. 09-46; Habermas, 1997, p. 12-13, p. $91 ; 2002 b$, p. 08), Habermas believes that a reconstruction of the basic principles of the modern European culture enables the reaffirmation of a moderated universalism which is adapted to contemporary 
conditions of individualism, multiculturalism and skepticism regarding exactly to the legitimation of a universalist epistemological-moral paradigm, avoiding also a resumption and a renewal of the conservative traditionalism based on a naturalized or on an ethnic normativity which is closed and blind to the cultural differences (see Habermas, 1997 , p. 16 , p. $148-149 ; 1991$, p. 166; 2002b, p. 01-02). Now, what characteristics have European cultural modernity which put it in a so high normative status? Such modern specificities, according to Habermas, appear clearly from a comparison between traditional worlds and the modern world - that is the sociological-philosophical starting point of the Habermas' theory of modernity.

Traditional worlds are based on an intrinsic and strong imbrication among nature, society and individuality, so that individual is subsumed by social dynamics, as social dynamics is subsumed by the nature. Such process means that nature appears as a normative model to social relations and stratifications, and to individual self-understanding as well. Here, only the magic can control the natural and social forces, not the human praxis concerning the nature and the social evolution (as modern science and politics do). The most important on Habermas' understanding of the traditional societies (such point is basic also to classical sociology) is the fact that traditional societies, because of that imbrication among nature, society and individuality, have not social mobility, as they have not a notion of individuality as separated from the own naturalized society. But why traditional societies have not social mobility? And why they have not a notion of individuality in a strict sense? Of course, because of the fact that such strong imbrication avoids the emergence and the consolidation of the institutional-cultural secularism, as well as the emergence and the consolidation of a notion of personality which is separated both of the nature and of the society. Thus, in traditional societies, social evolution and status quo are naturalized (not secularized), and the individuality are subsumed by such naturalization of the institutions and culture. That is the reason why traditional societies are not rational, as they do not generate rational forms of life: traditional societies are naturalized, based fundamentally on magic or on religion, in that their norms, practices, 
status quo and evolution are not a question to critic and to public discussion between individuals, but a result from a magical intervention in the world which leads to the societal naturalization. There is not social mobility or transformation in traditional societies, because they have not institutional-cultural secularism, not an individuality which is separated from the natural-social world. Then, there is not a rational form of life in traditional societies, for they do not need the dialogue and the social cooperation to the grounding of the norms and practices - traditional societies' norms and practices are based on naturalism and magic, and here social criticism has no place (see Habermas, 1999, p. 51; 2012a, p. 94-140).

Modern European culture is based on a strong separation between nature, society and individuality, in that (a) nature becomes a very physical world, i.e. a pure material constitution, accessible by a technical analysis from a scientific praxis, as (b) society becomes denaturalized and (c) individual becomes now the basic principle to the epistemological-moral-political foundation. Cartesian distinction between res cogitans and res extensa signifies exemplarily the separation between human constitution and natural constitution, between man and nature/animalism, as theories of social contract and natural law emphasize exemplarily both the individual's normative centrality and the institutional-cultural secularism. As consequence, cultural modernity is very explosive politically speaking, in the sense that modern culture generates a very acute social criticism. Indeed, modern culture is based on the societal denaturalization and on the strong individualism: in the first case, society is a human construction, its status quo is not defined by any naturalized or religious principle; in the second case, each individual is the only normative principle to political-cultural foundations, so the institutional-cultural legitimation depends of a social interaction or of a social contract between individuals. Here emerges the modern correlation between institutional-cultural secularism and strong individualism: denaturalized institutions and culture are legitimized and streamlined by a social praxis between individuals, because of the fact that the individuals are the only normative basis which remains in the modern societies after the end of the metaphysical-theological 
foundations (see Habermas, 2012a, p. 140-229; 2003a, p. 20, p.44, p.54; 2003b, p. 33; Honneth, 2003, p. 125-156, p. 271-280; Forst, 2010, p. 08-14, p. 276-345).

This is the reason why Habermas says that European cultural modernity is rational and enables a rational form of life. Indeed, we can see that, the moment in which naturalized institutional-cultural foundations are overthrow, secularized institutions and culture only can be legitimized by a social interaction (or communicative action) between all individuals and groups. This is the sense of Habermasian affirmation that cultural modernity is a rational form of life which generates a rational conduct of life: its secularism and individualism lead to a social contract based on a dialogical praxis, i.e. the individuals and groups must establish a dialogical social praxis with the scope to ground normative principles socially biding - only such dialogical praxis is the way and the path to the epistemological-moral-political legitimation in modern societies. To do that, they must renounce to naturalized or essentialist principles and arguments, assuming a formalist and decentralized normative basis. What signifies such formalist and decentralized normative basis? It means that individuals cannot assume an egocentric and an ethnocentric consciousness in order to perform a dialogical social interaction and to legitimize a notion of social normativity which will coordinate and orientate the social evolution and the individual action at all. In fact, the social agreement in modern societies cannot be egocentric and ethnocentric, because such characteristics make impossible any peaceful and democratic social interaction, the same way that they do no respect multiculturalism and radical individualism as the political starting point to the normative grounding of the modern societies (see Habermas, 2012a, p. 253-299, p. 384; 2012b, p. 87-202).

European cultural modernity enables the emergence and the development of a universalistic epistemological-moral consciousness which is based on the institutional-cultural secularism and on the strong individualism. Such modern condition leads to the consolidation of non-egocentric and non-ethnocentric social praxis, culture, way to legitimation and individual self-consciousness, which are the real 
meaning of the modern epistemological-moral universalism: a dialogical praxis between different individuals and cultures must assume a procedural, impartial and neutral consciousness, principles, practices and way to foundation, overcoming a naturalized and essentialist basis. That is the only possibility to the contemporary post-metaphysical societies, which are very multicultural and individualized (complex societies), i.e. the procedural paradigm - based on secularism and individualism, on a denaturalized notion of society, culture and morality - is the starting point to the current foundation of a comprehension of social normativity which can serve as critical, interventive and integrative epistemological-moral paradigm (see Habermas, 1990, p. 11-61; 2002a, p. 17-53). Modern universalism, therefore, generates democracy and human rights as the fundamental epistemological-moral contents resulting from institutional-cultural secularism and strong individualism. Such basic modern normative principles mean, first, the fact that non-egocentric and non-ethnocentric culture and consciousness are the basis of the modern societies, as European cultural modernity's heritage; they mean, second, a consolidation of a procedural epistemological-moral paradigm founded on the impartiality, neutrality and universalism as the only theoretical-political basis to legitimation of norms and practices in a contemporary multicultural world; and they mean, third, the fact that modernity, reconstructed by the notion of communicative action, can be sustained now as universalist epistemological-moral paradigm to critic, to intervention and to integration, based exactly on the notions of democracy and human rights. This modern normative legacy gives today a second chance for Europe to pursue and to perform a cosmopolitan ethical-political project (see Habermas, 2003c, p. 25-26, p. 71, p. 102-137; 2006, p. 10-60, p. 88-185).

\section{Human rights and modern debts}

Now, why European modern culture can offer a universalistic epistemological-moral paradigm to critic, to intervention and to integration? How human rights and democracy are universal values? Here 
emerges three specificities of the Habermas' theory of modernity which sustain such idea of democracy and human rights (modernity's legacy) as universal values to critic, to integration and to intervention, the same way that they allow the proceduralism, the impartiality and the neutrality as the basis of a post-metaphysical method to foundation of a universalistic epistemological-moral paradigm, namely: (a) the idea that all cultures seek the objectivity of their own values, which enables a formalistic model of epistemological-moral universalism; (b) the idea that European cultural modernity is the apogee of human evolution, a natural way of the traditional society's self-development; and as consequence (c) the idea that rationalism is the normative criteria do evaluation of the maturity of any particular culture, becoming the very own theoretical-practical basis to the critic, to the intervention and to the integration. According to Habermas, the first point (specificity "a") that we can observe when we analyze the social-cultural constitution of all peoples is the fact that all of them presuppose the strong objectivity of their intersubjective epistemological-moral norms. It is, sociologically and anthropologically speaking, the very fundamental human societal characteristic, in that every single society only can survive over time if it has conditions to ground and to sustain over time a biding notion of social normativity from which socialization and subjectivation (as correlative genetic process) are based on and streamlined by. It means two consequences: first, as I said above, Habermas believes that all cultures constitute and evolve themselves by the affirmation of a strong and binding notion of social normativity which is objective, not relative; second, if it is true, all societies maintain such social normativity's objectivity by social-institutional process of education and cultural training, which means that intersubjective moral values are inculcated through the everyday language or through a religious, magical or even juridical-political language - any way, communicative action is the cultural basis to the validation and education about intersubjective norms and practices. Therefore, all societies aim for the epistemological-moral objectivity of their own norms and practices, as all of them use the everyday language to ground, to inculcate and to educate their people into the binding collective values and traditions (see Habermas, 2012a, 
p. $119 ; 1989$, p. 143-233). From here we can perceive that universalism is not a philosophical phantasy, but a fact in all cultures, and that favors the legitimity of an epistemological-moral universalism correctly constructed and proper to contemporary times of consolidated pluralism. Despite the fact that the epistemological-moral contents are particularized according to each specific social-cultural context, the notion of objectivity or universalism is present everywhere.

With respecto to point (b), Habermas believes that human evolution follows the path and the way to the social-cultural modernization both in terms of institutional constitution and of cultural-epistemological consciousness. That is very interesting and defines the complete sense of the Habermas's recovery and renewal (from the overcoming of the modern philosophy of subject by the contemporary philosophy of language) of the European cultural modernity as basis of a universalistic epistemological-moral paradigm. Human evolution leads to the modernization, not to the traditionalism - human evolution is a slow, painful and progressive overcoming of the egocentric and ethnocentric traditionalism by a formalistic, procedural and cosmopolitan culture and epistemological-moral consciousness (see Habermas, 2012a, p. 140141, p. 326). Let's pay attention to such important idea: the human evolution at all starts as traditionalism and ends as modernization - without such fundamental thesis we cannot understand Habermas' theory of modernity nor his recovery and renewal of the European cultural modernity as paradigmatic normative model to ground a notion of universalism to contemporary societies (another important Habermasian idea is the fact that human evolution does not become traditionalism, as human evolution does not returns to traditionalism). So, there is a strong connection between modernization and human evolution, modernization (i.e. European cultural, social, political, economic and epistemological modernization) as human evolution: the overcoming of a traditional notion of epistemological-moral foundation which is attached to its own context, becoming non-reflexive and non-critical, by the modern individualism and institutional-cultural secularism which lead to a very critical and cosmopolitan cultural-epistemological 
consciousness based on the proceduralism, the impartiality, the neutrality and the universalism as normative basis to the praxis. Here, the core of human evolution is constituted as a modernization which overcomes egocentric and ethnocentric traditionalism.

The more impressive consequence (point " $c$ ") of such direct association between human evolution and modernization, between human evolution and the overcoming of traditionalism by modernization is the fact that rationalism (based on the communicative action, i.e. on the proceduralism, impartiality, neutrality and universalism) becomes the fundamental criteria to the evaluation and to the framing of all cultures. But why that? First, because of the fact that modern European culture is the apogee or the maturity of the human evolution at all - human evolution is the overcoming of traditionalism by modernization. So, modern European culture, the moment that it represents both the natural path of human evolution, and the mature cultural-epistemological stage for humankind, assimilates and embraces the very own traditional societies into its proceduralism. In other words, modernity contains within itself the traditionalism, as the traditionalism's path is to become the modernization. So, there is a connection and a linking between them, which implies in the possibility to a modern framing regarding the traditionalism's constitution and legitimation. Second, exactly by such connection between modernization and traditionalism (modernity was a traditional society; traditionalism will be a modern world), modern European culture - institutional-cultural secularization, individualism and decentered culture and consciousness - represents not only the ending point of traditionalism, but also its judge, its guide, its truth, at least in a strong way (see Habermas, 2002a, p. 08).

That is the reason why, according to Habermas, it is possible to measure the maturity of each culture by the analysis of its capability to rationalize its norms and its procedures, justifying them from a procedural practice and achieving a universal critical point of view. So here, rationalism becomes the epistemological-normative point to the evaluation of the maturity of each particular culture: rationalism is both a consequence of the modernity's overcoming of traditionalism and the traditionalism's path, the same way that it is constituted 
by a decentered culture and consciousness which is based on a very formalistic procedure of foundation which is, according to Habermas, sensitive to differences and capable to embrace and unify them into a universalistic and cosmopolitan epistemological-moral paradigm and ethical-political project. Now, from such association between human evolution and modernization, from such characteristics above mentioned, a modern universalistic epistemological-moral paradigm is legitimized to assume the role of criticism, framing and intervention concerning all contexts, principles and practices which do not respect human rights and democracy: as humankind's evolutionary apogee, modernity becomes the supreme normative criteria to evaluation of any form of life. Any critic to modernity can at best be assimilated without leading to the delegitimation of modernity, because, in the modernity's self-understanding, there is not a more high level than modern universalism, and modern universalism is so formal that it embraces and assimilates all critics or forms of life.

Now, I think that Habermas' theory of modernity, the moment that it assumes a double (but correlative) comprehension of the European modernity (a universalistic culture and a systemic institutional process), only can sustain the own modern culture and consciousness as normative basis to a universalistic epistemological-moral paradigm by ignoring their linking with the Realpolitik of the colonialism. In other words, the Habermas' theory of modernity, based on that reconstruction of a normative model of the modern European culture, only is possible by a historical-sociological blindness about the fact that there is not separation between such modernity's normative-cultural self-understanding and the modern Realpolitik of the colonialism. However, the Habermas' historical-sociological blindness concerning such intrinsic imbrication is intentional: as I am saying, just by such theoretical-political disconnection, the recovery and the renewal of a normative model of European cultural modernity can be performed and sustained as a universal and normative paradigm to critic, to intervention and to integration, which is valid even today (when we can perceive this imbrication). Habermas believes that such normative model of modern European culture can be used not only to criticize, to intervene and to 
integrate traditional contexts, but also to the very own modernization, which permises its political control and normative orientation. The Habermas's more important argument regarding such idea is that modern universalism is very formal to be used in many ways and senses, which means that it cannot be held responsible by colonization at all. But, as I showed above, the very theoretical-normative starting point of Habermas's theory of modernity is exactly the idea that European modernization (both in terms of culture and consciousness, and in terms of systemic institutional development) is the apogee of human evolution, the natural path to traditionalism, generating a universalistic form of life which guarantees the social normativity to a critical social theory and to a radical political praxis (see Habermas, 1997, p.143-144). Then, here, the modern epistemological-normative self-understanding, which differentiates modernity regarding the traditional forms of life, is the same than the dynamic of political-economic modernization which characterizes the developed contemporary societies in relation to primitive forms of production and socialization. On the one hand, modern epistemology and social normativism have a universal constitution and range; on the other hand, modern capitalism leads to a social integration which has a universalistic scope and way.

Such historical-sociological blindness of theories that use European modernity as normative, epistemological, political and economic model to critic, to integration and to intervention is absolutely common, and it consists in a direct separation between a normative model of modernity and the Realpolitik of colonialism. And those philosophical, sociological and historical theories have a very direct theoretical-political intention, i.e. to ground, to sustain and to perform a universalistic epistemological-moral paradigm which enables the critic, the integration and the intervention, attributing to modern institutions and culture the central role to organize and to judge in the name of the humanity at all, as I said above. Now, such historical-sociological blindness erases the connection between a normative model of modernity and the Realpolitik of modern colonialism by a simple fact: it does not understand this normative basis constituted by European culture and consciousness as linked and rooted on the Realpolitik of colonialism. 
As consequence, it conceives the epistemological-moral universalism as independent and overlapped to systemic modernization (the development of modern State, capitalism and the current cultural-economic globalization), so that it has the capability to frame and to sensitize such systemic modernization. However, such theories - and Habermas' theory of modernity in particular - cannot hide the fact that they conceive the modernity's emergence and development as an imbricated and dependent process which is based on the correlation between a self-affirmed universalistic culture and consciousness, and a systemic institutionalism (State, capitalism, globalization, technicism, scientism etc.). Here, the important theoretical-normative point is that the capitalism has generated the normative-cultural conditions to universalism, particularly the institutional-cultural secularism and the methodological-political individualism, the same way that capitalist globalization has integrated societies and cultures in a form of vital and institutional relation which establishes the modern principles and practices to all people - and these people can use them against modernity too.

There is a modern debt which was not paid, and the Aylan Kurdi's picture is the example of that: the eradication of colonialism both in terms of epistemology and culture, and in terms of systemic capitalist Realpolitik. The direct association between modernity and universalism as a final or more developed stage of human evolution and constitution is the obvious form of a recovery and of a renewal of the modern superiority regarding traditionalism. As I reconstructed from Habermas's theory of modernity, modernization (as normative culture and consciousness, and as systemic institutionalism) is the ending stage of human evolution. The own concept of modernity or modernization means such rupture with traditionalism (as a point of no return), giving a normative superiority to modernity regarding traditionalism, and directing modern dynamics against traditionalism - it seems to be the modernity's path and vocation. Now, what is interesting is the fact that not only Habermas, a very illustrated intellectual, can use such normative notion of modernity, but also a person as George W. Bush. Well, what it means? It means that there is not an objective use of the modernity's normative content, but a political use of it, which is linked 
to and dependent of the maintenance of the modernity's superiority and totalizing prosecution. A priori, modernity cannot guarantee the neutrality and the impartiality of its use as normative paradigm, because of the fact that it is not neutral or impartial, but politically linked and rooted in the modernization at all. That is a sufficient reason to deny such modern self-pretension both to conceive itself as a mature stage of human evolution and as a paradigmatic culture and consciousness to critic, to integration and to intervention for a globalized world. And that fact of the political use of the modernity by modernity itself leads me to argue that the very basic future for a normative-political understanding of modernity as universalism is, when the link between a normative model of modernity and the Realpolitik of colonialism is evident enough, the modernity's self-restraint and limitation, i.e. the refusal of the modern universalism as paradigmatic basis to critic, to intervention and to integration of a globalized world (from the modern standpoint, of course) and the reparation for the colonialism.

Such modernity's self-restraint and limitation are justified both by the illusion of the modern universalism as a mature stage of human evolution and of civilization (as if it were a natural or consequent evolutionary process of the humankind over time), as by the political use of the normative self-understanding for the colonialism (see Spivak, 2010; Mignolo, 2007). A self-restraint and limitation lead to the radical contraposition to cultural-economic globalization based on that normative-epistemological self-comprehension of modernity as enabling the universalism itself, as culture, institutions, politics and productive constitution and organization which are the basic alternative to contemporary world. A radical self-criticism of modernity by modernity allows to put again the critic of modernity as the theoretical-political central preoccupation, in the sense that modern universalism is not used anymore against traditionalism, but as a restraint and as a limitation of the modernity by modernity. This reduces modern epistemology to an internal critic and limitation of the modernity's tendency to rationalization and to universalism against traditionalism, which means that the normative universalism becomes directly against such modern colonialism (both epistemological and economic). Indeed, as I think, that 
is the major theoretical-political posture which we - the modernity's sons - must assume against our father/mother, i.e. the great danger to the stability of our contemporary societies and world is the direct and unstoppable prosecution of the cultural-economic modernization into all peoples and societies, in that the epistemological modernity and the cultural-economic modernization, in an imbricated sense and action, become the only way that we have to a better world. Such situation depoliticizes the modernity's contradictions, the unstoppable modern tendency to assimilate and to delegitimize all alternative paradigms and forms of life by such blind modern self-comprehension as a universalism form of thinking, living and social-productive organization.

\section{Some conclusions}

There are not only two options: or modernization, or traditionalism, as Habermas believes. The realistic theoretical-political option to us is exactly to turn epistemological-political universalism in particular and modernity's cultural self-understanding in general against the modernity itself, restraining it and limiting it in its tendency to rationalize and to assimilate all cultures and peoples into modern social-cultural constitution and dynamics. That is an important theoretical-political option and praxis to contemporary social movements, citizen initiatives and intellectuals who perceive such a historical-sociological blindness as the basis to the unstoppable and unceasing prosecution of modernization both as universalistic paradigm and as cultural-economic project of globalization. Such political option for the using of the epistemological-political rationalism as an direct internal critic to modernity leads to the refusal of the modern culture and consciousness as normative platform to the critic and to the framing of all forms of life, and to the reparation for the colonialism by modernity. Now, as conclusion, I want to discuss a little bit on this last idea. The reparation for the modern colonialism is a very urgent necessity for the contemporary times: the growth of national and international poverty, social inequalities and violence is the dramatic - but consequent - fact of the global 
prosecution of the cultural-economic modernization (see Piketty, 2014; Habermas, 2009). And it can be stopped by two political actions: first, the universal offer of social rights, as the Van Parijs' proposal of an unconditional basic income which allow individual and social emancipation from poverty and misery, and from market as well (see Van Parijs, 2014 , p. 15-50). Second, a radical international politics by social movements, citizen initiatives and intellectuals which has as central focus the critic to cultural-economic modernization, in order to restraining and limiting it, evaluating as we can change its destructive effects into the societies and into the global order, evaluating even the ecological impacts of an excessive industrialism and consumerism based on the immoderate use of natural resources. Above all, the reparation for the colonialism by modernity is a very fundamental task of the contemporary emancipatory theoretical-political forces. The critical social theory does not need to assume a universalistic foundation and range as condition to critic, to integration and to intervention, extending the paradigm of modernization to the traditional cultures. The critical social theory's more important task is exactly to use the modernity's normative self-comprehension against epistemological, cultural and economic modernization as an imbricated core and movement. Here, to limit and to restrain cultural-economic modernization is the same than to limit and to restrain the critical social theory only into an internal critic to epistemological-political and cultural-economic modernization. These are the two epistemological-political tasks for the reparation for colonialism by modernity.

\section{References}

DUBIEL, H. Que es el neoconservadurismo? Traducción de Agapito Maestre. Barcelona: Editorial Anthropos, 1993.

FORST, R. Contextos da justiça: filosofia política para além de liberalismo e comunitarismo. Tradução de Denilson Luís Werle. São Paulo: Boitempo, 2010. 
HABERMAS, J. Consciência moral e agir comunicativo. Tradução de Guido Antônio de Almeida. Rio de Janeiro: Tempo Brasileiro, 1989.

HABERMAS, J. Pensamento pós-metafísico: estudos filosóficos. Tradução de Flávio Beno Siebeneichler. Rio de Janeiro: Tempo Brasileiro, 1990.

HABERMAS, J. Ensayos políticos. Traducción de Ramón Garcia Cotarelo. Barcelona: Ediciones Península, 1997.

HABERMAS, J. A inclusão do outro: estudos de teoria política. Tradução de George Sperber e de Paulo Astor Soethe. São Paulo: Loyola, 2002a.

HABERMAS, J. O discurso filosófico da modernidade: doze lições. Tradução de Luis Sérgio Repa e de Rodnei Nascimento. São Paulo: Martins Fontes, 2002b.

HABERMAS, J. Direito e democracia: entre facticidade e validade (Vol. I). Tradução de Flávio Beno Siebeneichler. Rio de Janeiro: Tempo Brasileiro, 2003a.

HABERMAS, J. Direito e democracia: entre facticidade e validade (Vol. II). Tradução de Flávio Beno Siebeneichler. Rio de Janeiro: Tempo Brasileiro, 2003b.

HABERMAS, J. Era das transições. Tradução de Flávio Beno Siebeneichler. Rio de Janeiro: Tempo Brasileiro, 2003c.

HABERMAS, J. O ocidente dividido. Tradução de Luciana Villas Bôas. Rio de Janeiro: Tempo Brasileiro, 2006.

HABERMAS, J. Europe: the faltering project. Translated by Ciaran Cronin. Cambridge: Polity Press, 2009.

HABERMAS, J. Teoria da ação comunicativa (Vol. I): racionalidade da ação e racionalização social. Tradução de Paulo Astor Soethe. São Paulo: Martins Fontes, 2012a.

HABERMAS, J. Teoria da ação comunicativa (Vol. II): sobre a crítica da razão funcionalista. Tradução de Flávio Beno Siebeneichler. São Paulo: Martins Fontes, 2012b. 
HONNETH, A. Luta por reconhecimento: a gramática moral dos conflitos sociais. Tradução de Luiz Repa. São Paulo: Editora 34, 2003.

LYOTARDE, J-F. La diferencia. Traducción de Alberto L. Bixio. Barcelona: Editorial Gedisa, 1999.

MIGNOLO, W. D. La Idea de América Latina: la Herida Colonial y la Opción Decolonial. Traducción de Silvia Jawerbaum y Julieta Barba. Barcelona: Editorial Gedisa, 2007.

PIKETTY, T. O capital no século XXI. Tradução de Monica Baumgarten de Bolle. Rio de Janeiro: Intrínseca, 2014.

SPIVAK, G. C. Pode o Subalterno Falar? Tradução de Sandra Regina Goulart Almeida, Marcos Pereira Feitosa e André Pereira Feitosa. Belo Horizonte: Editora da UFMG, 2010.

VAN PARIJS, P. "Basic income and social justice: why philosophers disagree?". In: BAVARESCO, Agemir; SALATA, André; DANNER, Leno Francisco (Orgs.). Filosofia social \& políticas públicas. Porto Alegre: Editora Fi, 2014, p. 15-50.

Recebido: 14/09/2015

Received: 09/14/2015

Aprovado: 28/01/2016 Approved: 01/28/2016 